\title{
Design of facility layout with lean service and market basket analysis method to simplification of service process in the supermarket
}

\author{
Ukurta Tarigan $^{1 *}$, Uni Pratama P Tarigan ${ }^{1}$, Intan Hartanti Rahman ${ }^{1}$, and Indah Rizkya ${ }^{1}$ \\ ${ }^{1}$ Universitas Sumatera Utara, Department of Industrial Engineering, Faculty of Engineering, Jl. Almamater Campus USU Medan 20155, \\ Indonesia
}

\begin{abstract}
Supermarket company is a retail company in the field of services that sell various daily necessaries such as food, beverages, fruits, cosmetics, detergents, glassware and so forth. Problems that occur in this company is consumers are still looking for items to be purchased, notices of goods that are still wrong by the salesperson, miss communication occurs, the goods have not been neatly arranged, price tags are often lost, and items that are not complete. This resulted in longer service process time. The method used in overcoming this problem is using Lean Service and Market Basket Analysis method. The result of Lean Service method is eliminating waste in the company by using $5 \mathrm{~W}+1 \mathrm{H}$ concept. After the identification of waste, the company's layout is improved by using Market Basket Analysis method. In Market Basket Analysis method determined the number of samples, calculate the value of support factor, confident, and improvement ratio. The result of Market Basket Analysis method there is 14 products that have influence between one product with another. From these results obtained 3 alternative layouts and chosen the best layout alternative.
\end{abstract}

\section{Introduction}

Currently, the business world is rapidly growing with the existence of modern shopping centers. All of that cannot be separated from the advantages offered by each shopping center such as promotion, security, good service quality, completeness of goods and buyers can choose their own goods with personal taste. Not only that, good facility layout is needed for maintaining the convenience of consumers in shopping and the employees can easily perform activities such as, arranging items that will be placed on the shelves or any other available facility. Consumer satisfaction is an important thing because it can make consumer to reuse the service. Customer satisfaction is one of the goals of retail industries. One of the factors that affect the satisfaction of consumers is the product display [1].

Facility layout is defined as the procedure of arranging the physical facilities of the factory in order to support the smoothness of the production process [2]. By arranging the factory layout can improve product quality, facilitate the free flow of materials so as to improve the operational efficiency of the organization [3]. There are many procedures and algorithms that can assist facility planners to construct the new layout or improve the current layout $[4,5]$. To developing the layout, several alternatives are needed at order to choose the best layout and then optimize it. [6] A good facility design involves the systematic physical arrangement of various departments, workstations, machinery, equipment, storage areas and common areas in the manufacturing industry [7]

PT. XYZ is a retail that sells goods for everyday purposes. Strategic location and the low price is given by PT. XYZ makes this supermarket always visited by many people every day. However, it is necessary for this supermarket to improve the quality of service considering that there are many other supermarkets.

Although research on lean services is still in the early stages so many people are interested in applying lean practices in the service industry [8]. A proper approach to service activities must include a clear understanding of service and its inherent characteristics. $[9,10]$ In this research, the lean principle is suitable to be applied to reduce wastage. Where lean service is used as an approach to creating an effective internal service system so that the important information can get to the consumer quickly and with effective service $[11,12]$. In lean concept, standardization of procedure and continuous improvement become fundamental in the continuity of service process to improve the performance of a company.

Problems that occur in this company is consumers are still looking for items to be purchased, notices of goods that are still wrong by the salesperson, miss communication occurs, the goods have not been neatly arranged, price tags are often lost, and items that are not complete. So far, the arrangement of goods in supermarkets $\mathrm{XYZ}$ using the rules of an arrangement based on product type, size, and product characteristics

* Corresponding author: ukurta.tarigan@yahoo.com 
and has not seen in terms of consumer behavior. Therefore XYZ needs to analyze the layout of its store $[13,14]$.

\section{Research method}

The research begins with the review and data collection at PT. XYZ. The data collected from company documents is the number of goods sold in the company. The Lean Service method is used to determine service times and identify waste. Improvements made to reset the retail layout using Market Basket Analysis method.

\section{Result and discussion}

\subsection{Lean service}

The waste that occurred in XYZ is as follows:

- Waiting do for the next process step is the delay to get service, delivery, queue, response and timely acceptance.

- Errors In Document is an error that occurs when filling the document, repeats the details of the form, re-copying the information.

- Unnecessary Motion is delay some time and does the unnecessary movement.

- Transport of document is waste generated from the clarification search in determining the location that can cause duplication

- Doing work not requested that can happen out-ofstock, can not provide what is needed, substitute product or service.

- Backlog in work queue is a failure to establish rapport, and there is no maximum use of facilities and equipment

- Process step and approvals are defects of products in product service bundle, loss or damage of resources.

Questionnaires were carried out to choose which waste to choose from as the solution design. Questions posed to the company are about seven wastes: waiting do for the next process step, errors In Document, unnecessary motion, transport of document, doing work not requested, backlog in work queue, and process step and approvals from the open questionnaires deployment, the attributes appear is as follows:

Table 1. Seven waste of service attribute.

\begin{tabular}{|c|c|}
\hline Seven Waste of Service & Waste of Service Attributes \\
\hline $\begin{array}{c}\text { Waiting do for the next } \\
\text { process step }\end{array}$ & Placement to shelves \\
\hline & Waiting to be served \\
\hline Errors in Document & Damaged goods \\
\hline & Note errors \\
\hline Unnecesary Motion & Employee back and forth \\
\hline Transport of Document & Unnecessary transport of equipment \\
\hline & Unnecesarry transport of goods \\
\hline Doing work not requested & Stock waiting for the goods to run out \\
\hline Backlog of work queues & Facilities not in used \\
\hline Process Step and Approvals & Help find products \\
\hline
\end{tabular}

After the attributes obtained from the open questionnaire, then the spread of questionnaires followed by the closed questionnaire and tested the validity and reliability of the formula:

\subsubsection{Validity test}

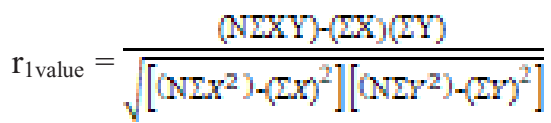

With $\mathrm{r}$ table $=0,514$

$$
\begin{aligned}
& r_{1 \text { value }} \quad=\frac{(15 \times 786)-(30)(365)}{\sqrt{\left[(15 \times 82)-(30)^{2}\right]\left[(15 \times 9451)-(365)^{2}\right]}} \\
& r_{1 \text { value }}=0,5414
\end{aligned}
$$

\subsubsection{Reliability test}

$$
\begin{aligned}
& \mathrm{r}=\left[\frac{k}{k-1}\right]\left[1-\frac{\Xi \sigma_{x}^{2}}{\sigma_{y}^{2}}\right] \\
& \mathrm{r}=\left[\frac{\mathbb{k}}{\mathrm{k}-1}\right]\left[1-\frac{\Xi \sigma_{\mathrm{k}}^{2}}{\sigma_{y}^{2}}\right]=\left[\frac{11}{11-1}\right]\left[1-\frac{12,764}{196,506}\right]=1,028
\end{aligned}
$$

The order of waste obtained from closed questionnaires is as follows:

Table 2. Order of waste.

\begin{tabular}{|c|c|c|}
\hline Seven Waste of Service & $\begin{array}{c}\text { Average } \\
\text { Weight }\end{array}$ & Rank \\
\hline Waiting do for the next process step & 39 & 2 \\
\hline Errors In Document & 30,5 & 5 \\
\hline Unnecessary Motion & 28 & 6 \\
\hline Transport of document & 26 & 7 \\
\hline Doing work not requested & 31 & 4 \\
\hline Backlog of work queues & 55 & 1 \\
\hline Process step and approvals & 32 & 3 \\
\hline
\end{tabular}

From the selected VALSAT election result, Process Activity Mapping (PAM) with the weight of 1419,5 is chosen, then it can be identified the Value Stream Mapping by using the tools. Comparison between value added and non value added activity can be seen in Fig. 1.

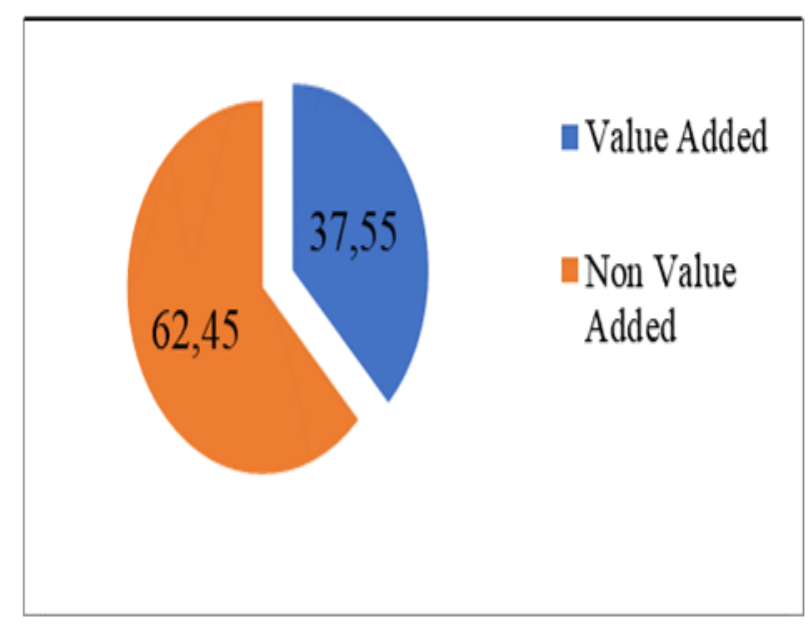

Fig. 1. Pie Chart of Value Added and Non-Value Added Activity. 
From the pie chart shows that the percentage of value added time activity is only $37.55 \%$ of the overall service process operation activity in XYZ and for non value added time is $62.45 \%$. Based on the result of the identification of the process activity, activity elimination is carried out for the activities that are considered to have no value,

- Waiting for inspection result

- Demolition of goods in the warehouse

- Brought to check the identity of goods/products

- Brought to price tagging place

- Waiting in front of the computer

- Brought goods to shelves

- Put stuff on the shelf

\subsection{Facility arrangement}

One of the proposed supermarket improvements to reduce service waiting time is about the arrangement of facilities. The arrangement of supermarket facilities is done by using Market Basket Analysis (MBA). The steps of MBA method is as follows:

\subsubsection{Grouping products}

Products are grouped into 4 kinds of rack presentation divided into two kinds of the main rack, storefront, cooling, and free presentation.

\subsubsection{Number of samples}

The data entered is the sales data for August 2017 that is 8432. From the population of this data then sought the number of samples by using Slovin formula.

$$
\mathrm{n}=\frac{\mathbb{N}}{1+\mathrm{N}\left(\mathrm{d}^{2}\right]}=\frac{8432}{1+8432\left(0,05^{2}\right)}=381,884 \approx 382
$$

\subsubsection{Support factor}

The formula for finding support factor value is as follow:

$$
\mathrm{S}=\frac{\mathrm{m}}{\mathrm{N}}
$$

Examples of support factor calculations for snack products are as follows

$$
S_{\text {snack }}=\frac{64}{382}=0,1676=16,76 \%
$$

\subsubsection{Confidence}

At this stage as many as 14 products then the calculation of products to be sought the value of confidence of each pair of products are as follows:

$$
\mathrm{p}=\frac{\mathrm{n} !}{(\mathrm{n}-1) !}=\frac{14 !}{(14-2) !}=182
$$

Examples of confidence calculations for couples of coffee and snack products are as follows:

$$
\begin{aligned}
& \mathrm{S}_{\mathrm{a} \rightarrow \mathrm{b}}=\frac{\mathrm{m}}{\mathrm{N}} \\
& \mathrm{C}_{\mathrm{a} \rightarrow \mathrm{b}}=\frac{\mathrm{S}}{\mathrm{a}}
\end{aligned}
$$

Product set 18 (coffee) and 13 (snack). Number of transaction :

$$
\begin{gathered}
\text { Kopi }+ \text { Snack }=32+18=50 \\
\mathrm{~S}_{13 \rightarrow 5}=\frac{50}{382}=0,1309=13,09 \% \\
\mathrm{C}_{13 \rightarrow 5}=\frac{13,09 \%}{16,76 \%}=78_{2} 13 \%
\end{gathered}
$$

The value of support and confidence is valid if the value of support s $(>5 \%)$ and confidence c $(>30 \%)$. Terms of the value obtained from the company.

\subsubsection{Improvement ratio/lift}

Improvement ratio can show the effect of one product to another. The ratio of improving ratio is as follows:

$$
I_{a \rightarrow b}=\frac{s}{s_{a} \times s_{b}}
$$

Examples of calculation of improvement ratio for coffee and snack products are as follows:

$$
I_{13 \rightarrow 5}=\frac{13,09}{16,76 \times 9,95}=7,85
$$

Improved ratio value is said to be valid if the value of I $(>1)$ means there is an influence between the product one with the other

\subsubsection{Activity relationship chart}

Activity Relationship Chart (ARC) is created to determine the degree of proximity and know the reasons for one product with another must be brought closer or away. The reasons used in making ARC are as follows:

- Fresh and frozen products

- Similar product (food and non-food)

- Affect the nature (chemical)

- No relationship

From the calculation of improvement, ratio obtained 14 types of products used in making ARC. Here is the $\mathrm{ARC}$ of the selected product. 


\begin{tabular}{|c|c|}
\hline 4 & Beverage box \\
\hline 5 & Bottle drink \\
\hline 8 & Canned drink \\
\hline 9 & Powder drink \\
\hline 13 & Snack \\
\hline 16 & Candy \\
\hline 18 & Coffee \\
\hline 22 & Biscuit \\
\hline 35 & Bath soap \\
\hline 40 & Parfume \\
\hline 44 & Stationary \\
\hline 65 & Herbs \\
\hline 69 & Cigarette \\
\hline 70 & Drug \\
\hline
\end{tabular}

Fig 2. Activity relationship chart.

\subsubsection{Product relationship}

Product relationship is made to help drawing the layout and can be used to illustrate the proximity of the product

\subsubsection{Layout}

Layout design also observe the number of products contained in the supermarket

- Layout 1 ismade with attention to product proximity relation (confidence) and support. Products that have a relationship will be brought closer to stimulate the occurrence of the buying impulse. High-support products are laid out in the back allowing consumers to explore store shelves.

- Layout 2 also puts products with high support and has many relationships in the middle of the store, so it can easily connect with other products.

- Layout 3 puts the product with great support up front to entice consumers into the store.

\subsubsection{Selection of selected layout}

The layout assessment has the following criteria

- Proximity of impulse buying products (confidence)

- Product efficiency with great support

- Proximity of fresh \& frozen products

- Proximity of similar products

- Product closeness with strong chemical properties

The results of the assessment can be seen in Table 3 .
Table 3. Layout assesment.

\begin{tabular}{|c|c|c|c|}
\hline \multirow{2}{*}{ Criteria } & \multicolumn{3}{|c|}{ Layout } \\
\cline { 2 - 4 } & 1 & 2 & 3 \\
\hline 1 & 8 & 8 & 8 \\
\hline 2 & 6 & 5 & 9 \\
\hline 3 & 8 & 6 & 8 \\
\hline 4 & 8 & 7 & 8 \\
\hline 5 & 8 & 3 & 9 \\
\hline Total & 38 & 29 & 42 \\
\hline
\end{tabular}

From the above scoring table, it can be seen that the layout with the total value is the layout 3 . So, layout 3 is chosen to be the recommendation of the XYZ supermarket layout improvement. The selected layout can be seen in Fig. 3 below.

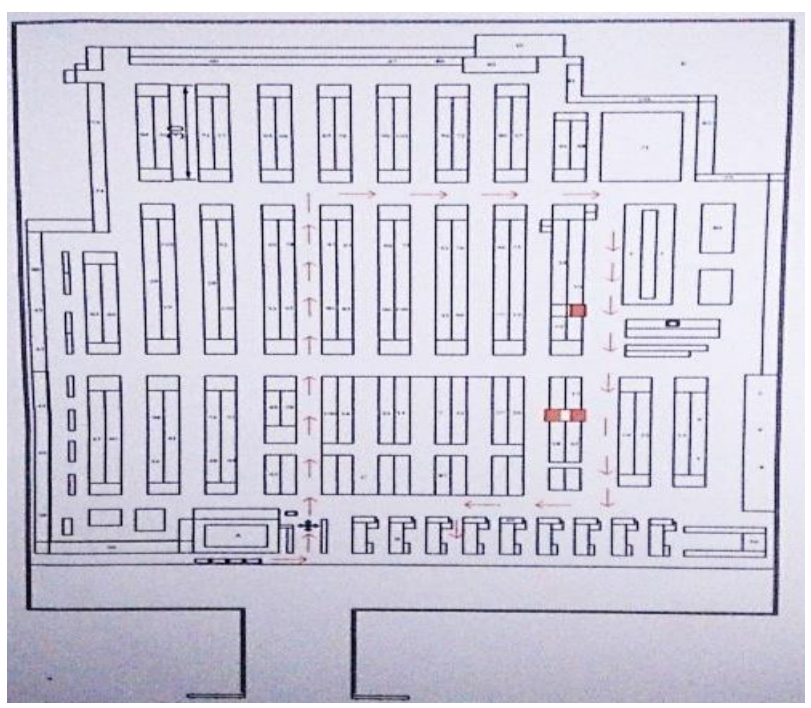

Fig. 3. Selected Layout.

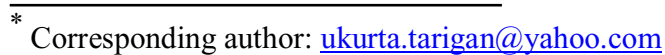




\subsubsection{Corrective action}

By eliminating activities that belong to activities that do not provide added value (Non Value added) in table 4. below.

Table 4. Non-Value Added Service Process Elimination.

\begin{tabular}{|c|c|}
\hline Activities & Time (Second) \\
\hline Waiting in front of the computer & 1440 \\
\hline Placing Goods into Shelves & 4200 \\
\hline
\end{tabular}

Thus, the calculation of the efficiency of the process cycle and the speed of the new process is as follows [15]:

Process Cycle Efficiency

$$
\begin{gathered}
\mathrm{PCE}=\frac{\text { Value Added }}{\text { Non Value Added }} x 100 \% \\
\mathrm{PCE}=\frac{10200}{20890} \times 100 \%=0,4885 \times 100 \%=48,85 \%
\end{gathered}
$$

Velocity Process

$$
\begin{gathered}
\mathrm{VP}=\frac{\text { Number of Activities }}{\text { Lead Time Process }} \times 100 \% \\
\mathrm{VP}=\frac{12}{0,4885}=24,56
\end{gathered}
$$

To calculate the Value Stream Process (VSP) value before eliminating the process activity, as follows:

Value Stream Process $(V S P)=$ Process velocity $\mathrm{x}$ Amount of activity contained in process VSP $=22.83$ stages / hour x 14 stages $=319.62$ hours .

Meanwhile, after eliminating activities that do not provide added value, namely:

Value Stream Process $($ VSP) $=$ Process velocity $\mathrm{x}$ Amount of activity contained in process VSP $=16.73$ phase $/$ hour x 12 stages $=200.76$ hours.

Thus, the difference between the value of the value stream process before and after is: (319.62 - 200.76) hours $=118.86$ hours.

\section{Conclusions}

Wastage that happens at supermarket $\mathrm{XYZ}$ is waiting to do for the next process step, errors in the document, unnecessary motion, transport of document, doing work not requested, backlog in work queues, and process step and approval. Service process improvement is done by lean service method by identifying the root of problem using $5 \mathrm{~W}+1 \mathrm{H}$. The comparison of service time before repair is 319.62 hours and after the repair is 200.76 hours. There are 14 kinds of goods which have activity relation level for some reason, fresh $\&$ frozen product, similar product (food \& non food), affect nature (chemical), and no relationship. In Market Basket Analysis method there are 3 alternative retail supermarket layout. Of the three alternatives, one of the best selected by the company's management with the assessment of each layout 1 is 38 , layout 2 is 29 , and layout 3 is 42 .
In this research, the authors would like to thank profusely to Universitas Sumatera Utara that gives chances to publish and develop author in the process.

\section{References}

1. A. Agestyana, Perbaikan Tata Letak Produk Di Assalaam Hypermarket Dengan Metode Market Basket Analysis (2016)

2. J. Apple, Plant Layout and Material Handling, 3 (1997)

3. S. Wignjosoebroto, Tata Letak Pabrik dan Pemindahan Bahan. Guna Widya (2000)

4. W. Tompkins, Brozer, Tanchoco, Facilities Planning, John Wiley \& Sons, Inc (2010)

5. Y. Ojaghi, Production Layout Optimization for Small and Medium Scale Food Industry (2015

6. S. Wignjosoebroto, Pengantar Teknik dan Manajemen Industri. Guna Widya (2009)

7. A. Entezari, Facilities Planning. Tehran: Jahan Jame Jam (2005)

8. BS Kallurkar, et al., Literature Review on Efficient Plant Layout Design, International Journal of Industrial Engineering Research and Development (2016)

9. M. Richter, R. Souren, Difficulties of economic defining a service: a production theoretical and scientific approach, Ilmenau Institute of technology (2008)

10. D. E. Bowen, Youngdahl (1998). Lean service: In defense of a production-line approach, International Journal of Service Industry Management (1998)

11. Y. Ojaghi, Production Layout Optimization for Small and Medium Scale Food Industry (2015)

12. G. Reig Grau, Market Basket Analysis in Retail, Computer Science Departement (2017)

13. M. Rother, J. Shook, Learning to See, Value Stream Mapping to Create Value and Eliminate Muda. The Lean Enterprise Institute, Inc (2003)

14. R. Wick Michael. 2006. Using Market Basket Analysis to Integrate and Motivate Topics in Discrete Structure. University of Wisconsin - Eau Claire.

15. H. Purnomo, Hari, Perencanaan dan Perancangan Fasilitas, Graha Ilmu 1 (2004) 